\title{
Educational Curriculum Scenario Planning in Facing Revolution 4.0
}

\author{
Koento P.N. Irianto ${ }^{1}$, Kristina Setyowati ${ }^{2}$, Rino Ardhian Nugroho ${ }^{3}$ \\ ${ }^{1}$ Master Program in Public Administration Department, Faculty of Social and Political Sciences, Universitas \\ Sebelas Maret, Indonesia (email: koentoseptember92@gmail.com), ${ }^{2}$ Public Administration Department, Faculty of \\ Social and Political Sciences, Universitas Sebelas Maret, Indonesia, ${ }^{3}$ Public Administration Department, Faculty \\ of Social and Political Sciences, Universitas Sebelas Maret, Indonesia
}

\begin{abstract}
Education in Indonesia is still referring to the 2013 curriculum system, where the system wants more interaction between students where students are demanded to be more active in the classroom teaching system, while the teachers only act as companions in the class. However, with the 2013 curriculum system, many students were unable to adjust the curriculum, especially the teachers also had too many teaching hours. Learning hours that are too long cause students and teachers to be more tired in the teaching and learning process. The implication is that too many study hours are charged to students so they cannot participate in activities outside of their school environment. The research in this paper will use the Systematic Literature Review research method and use a database that has been set. The results of this study will be used by researchers as a planning scenario in preparing an ideal educational curriculum and can face revolution 4.0 so that later the quality of Indonesia's next generation can be better in terms of quality education.
\end{abstract}

\section{Keywords:}

school; teaching; learning; technology

\section{Introduction}

The curriculum is a set of subjects and educational programs provided by educational institutions that contain lesson plans that will be given to participants in one period of education. The preparation of the subject matter is adapted to the conditions and abilities of each level of education in the field of providing education as well as employment needs. The length of time in a curriculum is adjusted to the aims and objectives of the implemented education system. This curriculum supports to direct education towards the direction and objectives needed in full learning activities. For this reason, the government has always agreed to adjust the curriculum to provide an educational curriculum that is in line with the revolutionary struggle 4.0. Currently the latest law that the government has set is Minister of Education and Culture Regulation Number 24 of 2016 concerning Core Competencies and Basic Competencies for Learning about the 2013 Curriculum in Basic 
Education and Secondary Education regarding a number of reports that have been amended as follows: Between Article 2 and Article 3 is inserted 1 (one). Article 2A (1) Information on Content in Elementary Schools / Madrasah Ibtidaiyah (SD / MI) can be used as a learning tool and/or learned through extracurricular and/or local loading. (2) Informatics subjects in Junior High Schools / Madrasah Tsanawiyah (SMP / MTs) and Senior High Schools / Madrasah Aliyah (SMA / MA) are included in the Basic Competencies used as learning facilities. 2. Core Competencies and Basic Competencies Lessons on the 2013 Curriculum on Basic Education and Secondary Education were approved in Minister of Education and Culture Regulation No. 24 of 2016 concerning Core Competencies and Basic Competencies for Learning in the 2013 Curriculum in Basic Education and Secondary Education with the help of Core Competencies and Competencies Elementary Informatics Basic SMP / MTs in sequence number 60 and Core Competence and Basic Competency in Information SMA / MA in sequence number 61 so that they are in accordance with those designated by the District which is an inseparable part of this Ministerial Regulation. The latest curriculum objectives currently emphasize more on competencies, namely (1) spiritual attitude competencies, (2) social attitudes, (3) knowledge, and (4) skills. This competency is learned through extracurricular, co-curricular and/or extracurricular learning processes.

The formulation of Competency in Spiritual Attitude is "Appreciating and living the teachings of the religion it adheres to". The formulation of Social Attitude Competency is "Showing honest behavior, discipline, responsibility, caring (tolerance, cooperation), polite, and confident, in interacting effectively with the social and natural environment within the reach of relationships and their existence". Both of these competencies are achieved through indirect teaching (indirect teaching), which is an example, habituation, and school culture by taking into account the characteristics of the subjects and the needs and conditions of students. Growth and development of attitude competencies are carried out throughout the learning process and can be used as teacher considerations in developing the character of learners further. Knowledge Competencies and Skills Competencies are formulated as follows. Core Competencies 3 (Knowledge) Core Competencies 4 (Skills) 3. Understanding knowledge (factual, conceptual, and procedural) based on curiosity about science, technology, art, culture related to phenomena and events seen in the eye. 4. Trying, processing, and presenting in the realm of concrete (using, unraveling, composing, 
modifying, and making) and abstract domains (writing, reading, calculating, drawing, and composing) following what is learned in school and other similar sources in point of view/theory. Then some competencies lead to computer engineering policy, mastering technology in the sense of being very important in supporting the quality of education in Indonesia. The details regarding the mastery of computer engineering include 1 . Get to know the functioning of the hardware and operating system, and applications. 2. Observing when a device (for example a cellphone, tablet) is turned on until it is ready to use. 3 . Shut down the computer properly. 4. Explain the types of interactions with the standard interfaces of various devices. As for core competencies and basic competencies for senior secondary education in Indonesia, including four competencies, namely (1) spiritual attitude competency, (2) social attitude, (3) knowledge, and (4) skills. The competency is achieved through extracurricular, curricular and/or extracurricular learning processes.

From the little picture above about the competency standards that the government has determined, the government also wants to provide the basics of knowledge related to information technology. The standard of competency achievement is optimal if the facilities owned by the school are sufficient. Behind the fact that schools and teachers are wellpositioned to act as a resource that can be a potential in providing school-based psychosocial support (Morrison and Allen, 2007) lack of resources, too heavy curriculum, time constraints and various demands the complexity that teachers get means that such responsibilities will be difficult to fulfill by the teacher (Bhana, 2006).

The government itself has adopted several policies to support the implementation of a good education, including making arrangements regarding decentralization in the education system. The decentralization of education is urgently needed by Indonesia today to improve the progress of education in Indonesia. Education in Indonesia should be able to synergize with the potential of their respective regions where this is the realm of Regional Government. The Central Government should be able to give authority to the Regional Government to provide decentralization in education for the achievement of quality education in the face of the 4.0 revolution which is the biggest challenge for the world of education today.

Education that emphasizes the approach of local wisdom and regional potential is considered more appropriate by some parties because later this will increase local potential 
in managing regional wealth and be able to absorb the workforce for school graduates. So those students who are already in high school will no longer experience difficulties at this time. Moreover, the current 4.0 revolution can be a threat to all regions and all walks of life. It did not rule out there will be some new challenges that could become obstacles to the progress of the region such as unemployment, injustice and several other cases. So that education decentralization is needed to be able to support the quality of education in Indonesia in the face of the 4.0 revolution.

The understanding of the decentralization of education according to (Hurst, 2000), "the decentralization process implies the transfer of certain functions from small groups of policy-makers to a small group of authorities at the local level" in other words decentralization is the process of handing over functions from a small group of policymakers to a small group of power holders at the local level. The Hurst definition clearly illustrates the process of handing over government functions which are then given to local governments. While the definition of decentralization according to (Chau, 2000), decentralization on the concept of delegation of power to local governments, to increase efficiency in the use of resources.

While decentralization in the Big Indonesian Dictionary (KBBI) suggests that the government system gives more power to local governments. Furthermore, according to the definition of decentralization (Hoogerwerf, 2010), decentralization is as recognition or transfer of authority by lower public bodies to independently and based on their interests take decisions on governance arrangements, as well as the structure of authority resulting from that. "Decentralization" means the transfer of the authority of the Central Government administration to autonomous regional governments to regulate and manage government affairs in the Unitary State of the Republic of Indonesia (Law Number 32/2004, Article 1 number 7 Decentralization). The transfer of authority is manifested in the form of 1) Deconcentration, constituting the delegation of governmental authority by the Central Government to the Governor as the representative of the government and/or to vertical agencies in certain regions (Law No.32 / 2004 Article 1 number 8) and 2) Duties assistance, is the assignment of the Central Government to the regions and/or villages from the provincial government to the district/city and / or village as well as from the district/city government to the village to carry out certain tasks. (Law No.32 / 2004 Article 1 number 9). Educational 
decentralization carried out in various countries is part of the overall education reform process and is not just part of the process of regional autonomy and financial decentralization (Burki, 1999). Furthermore, the decentralization of education is a process of giving broader authority in the field of education policy and funding aspects from the Central Government to local governments and at the same time, greater authority is also given to schools in the form of School-Based Management (SBM).

Logical consequences in the implementation of decentralization have an impact on various sectors, including the education sector which incidentally concerns the national education system. Therefore, the Government feels the need to make adjustments to UUSPN Number 2/1989 to UUSPN Number 20/2003. Some fairly basic changes to the law include 1) aspects of democratization and decentralization of education; 2) community participation, and 3) global challenges. Changes in the management of education autonomously due to this decentralization, at least it is assumed to have an impact on a) expansion and equitable access to education; b) improving the quality and relevance of education; c) financial efficiency, and d) administrative efficiency. Therefore, the decentralization of education requires a strong democratic foundation in the form of legal regulations, transparency, and efficiency, as well as involving stakeholders. Conceptually, there are two types of education decentralization, namely: 1) decentralization of authority in the field of education in terms of education policy and funding aspects from the Central Government to local governments (provincial, district/city) and 2) decentralization of education with a focus on giving more authority big at the school level. The first concept of decentralization of education is mainly related to regional autonomy and decentralization of government administration from the Center to the regions, while the concept of decentralization of education that focuses on giving greater authority at the school level is carried out with motivation to improve the quality of educational outcomes (Burki, 1999).

A good education system has been implemented in several countries, especially in this field of education, in Singapore which has become one of the best education systems in the world demanding that students be able to master the field of science. Singapore has a regulation where compulsory education is from 6 years to 12 years which must be implemented within 6 years. Then proceed to the second stage of education which is 12 years to 18 years which is traveled at the same time that is 6 years (Erkan, 2013). 
The definition of revolution 4.0 is still very diverse and is still in the research and development stage. Revolution 4.0 is a comprehensive transformation of all aspects of the industrial process by combining digital technology and the internet with conventional industries (Merkel, 2014). Revolution 4.0 emphasizes the definition of the speed element of information availability, namely in an industrial environment where all entities are always connected and able to share information (Schlechtendahl, 2015). A deeper and more technical understanding of revolution 4.0 is an integration of Cyber-Physical System (CPS) and the Internet of Things and Services (IoT and IoS) into an industrial process that includes manufacturing and logistics and other processes (Kagreman, 2015). Cyber-Physical System (CPS) is a technology to combine between the real world and the virtual world. Using this integration can be generated through integration between physical and computational processes (embedded computers and network technology) in a closed-loop (Lee, 2008).

Revolution 4.0 has now gone through a fairly long phase since it was first rolled out in the first British country to have invented a steam engine, then continued to other findings as a result of the Development of Rev 4.0 4.0. While in this decade the world has been confronted with the 4.0 revolution that all countries will share in its impact and implications. The world of education is the main base of this existence because students will be forged and will get an education that must be able to answer this 4.0 revolution.

Until the presence of decentralization in the world of education can be one of the accesses or processes in improving the quality of education to face the 4.0 revolution. Decentralization in the world of education will be able to develop potentials in each region where each regional potential, especially in Indonesia, is very diverse because Indonesia is a country of origin and has diverse cultures and regional potentials. However, with the decentralization of education still refers to the standards set by the central government, the regional government only has the authority to develop the potential of the region but can not be separated from the standards that have been set. Regional governments, in this case, have the opportunity to develop the potential of their regions, by developing their regional potential, students will have special expertise not possessed by students from other regions. Not only by developing regional potential, but decentralization of education can also make local governments develop students' interest in learning with technological advances. This technological progress can be based on information technology (internet) or by using other 
modern technologies. As for the focus in this research, the researcher wants to further study the education system that took place in Indonesia in the 4.0 revolution from the perspective of the field of public administration science. This study aims to provide an in-depth analysis of scenario planning in the face of the 4.0 revolution in education. So that later can be input to the government to be able to improve education in Indonesia.

\section{Method}

This research was conducted using literature study studies from accredited international journals and accredited national journals especially journals that discuss the education system that takes place in Singapore as a basis for comparing the education system that takes place in Indonesia. Data obtained through studies that have been examined as the results of previous research reports, journal articles, and other supporting data will be the basis of theory in writing this research. The data is then analyzed using the theory of human resource management and decentralization. So that it will produce new data in accordance with the research subject that will be analyzed again to design an appropriate curriculum to deal with the times, namely the 4.0 revolution, especially in the field of education so that the next generation is ready to face the challenges of the 4.0 revolution.

Through this literature study, it will later be re-elected in accordance with the theories and concepts needed to produce scenarios in developing the curriculum of the world of education in Indonesia, so that the Indonesian government can prepare the next generation of the nation that is able to compete with global competition. The capacity that cannot be increased in the world of education in Indonesia is inseparable from the human resources they have and the education system that is taking place in Indonesia. The existence of decentralization in the field of education will be able to influence the quality of education in Indonesia which in turn can produce a generation of nations that can compete to face the global competition of revolution 4.0. Educational decentralization will be able to develop innovations held by education organizers in Indonesia in improving the quality of their students in the face of global competition 4.0 revolution. Local governments can innovate in conducting education with the decentralization of education, but this decentralization of education also does not reduce aspects of the standard of education that 
have been determined by the central government. So that the quality standards of education that have been set have the same standards throughout Indonesia.

\section{Result and Discussion}

Related to decentralization and regional autonomy, it can be compared to two sides of a coin that cannot be separated from one another. The area of autonomy is a consequence of the principle of decentralization in the administration of government in an area. In essence, every state, whether it is democratic or socialist, there will be no state that only uses the principle of centralization in the administration of its government. Likewise, on the contrary, it is impossible for a country in the administration of government to be based only on the principle of decentralization. In practice, the administration of the two principles of government complements each other to be able to achieve a goal of implementing the governance of his country. Then, if it is related to decentralization in the world of education, that is, giving the authority of the Regional Government by the Central Government in organizing education in accordance with the capabilities of its local potential, this will provide opportunities for local communities to develop the potential of their respective regions.

While conceptually speaking, there are two types of education decentralization, namely: 1) decentralization of authority in the field of education in terms of education policy and funding aspects from the Central Government to local governments (provincial, district/city) and 2) decentralization of education with a focus on providing authority bigger at the school level. The first concept of decentralization of education is mainly related to regional autonomy and decentralization of government administration from the Center to the regions, while the concept of decentralization of education that focuses on giving greater authority at the school level is carried out with motivation to improve the quality of educational outcomes (Burki, 1999).

The goals and orientation of the decentralization of education vary greatly based on the experience of decentralization of education carried out in several countries such as Latin America, the United States, and Europe. When decentralization is the aim of granting greater authority in the field of education to local governments, then the focus of decentralization of education undertaken is on delegation of greater authority to local 
governments or to the education council and/or school committee. Implicit in the education decentralization strategy such as this is a target to achieve efficiency in empowering resources (energy, materials and education funds come from the Government and the community). Furthermore, when the goal of education decentralization is to improve the quality of the teaching-learning process and the quality of the results of the teachinglearning process, the decentralization of education is more focused on reforming the teaching-learning process. In this case, the participation of parents in the teaching-learning process is considered one of the determining factors.

From the experience of developed countries of the Organization for Economic Cooperation and Development (OECD) and several Latin American countries that have decentralized education, Patrinos, Harry A. and David L. Ariasingam (1997) concluded that in countries that are members of the OECD, authorities in terms of determining textbooks, learning methods, and responsibilities in implementing school development plans tend to apply at the school level and do not depend on the level of decentralization in the administration of government.

Observation of the decentralization of education in Latin American countries shows that the authority to determine the core curriculum remains with the Central Government. Likewise, the authority in carrying out national exams or midterm exams that are enforced nationally, so there will be no more cheating in organizing education. This applies generally in Latin American countries and does not depend on the level of decentralization in the administration of the respective states. The decentralization of education that took place in Latin American countries is part of the political and fiscal decentralization of governance, from a centralized education system to a system that gives greater authority to local governments that involve community participation. It is hoped that the decentralization of education will be able to increase the quantity and quality of education. One way to prepare for the decentralization of education is to identify the factors that influence the process and outcomes of teaching and learning, especially from top schools.

It can be concluded that superior schools have the following characteristics: a) strong leadership, b) teaching staff with high qualifications and commitment, c) focus on the learning process, and $\mathrm{d}$ ) are responsible for the results achieved (public accountability). The process of decentralization in the field of education which includes giving greater authority 
to local governments in budget allocations and education planning in the regions, as well as giving greater authority to schools in terms of teacher management, funding, headmaster selection, management of teaching and learning processes intended to improve - Improve the quality and relevance of education (Burki, 1999).

Therefore, the implementation of education decentralization is expected to emerge effective schools referring to the principle of school-based management (SBM). In essence, SBM is a form of authority of the Central Government to the education unit (school) in managing learning activities programs in their respective schools through deliberation of all components of school residents (principals, teachers, students, parents, students, school committees and/or other stakeholders, In other words, all school activities are carried out on the basis of deliberations and consensus among school residents Furthermore, the principal figure is expected to have someone who has reliable managerial skills and is chosen transparently through the stages of the selection process from the nomination to the determination candidates become by taking a variety of special assessment (test) (talent scouting) while still considering the voice of the school community before being designated as the principal, the position of the principal is determined based on a certain period of time and can be extended as long as the person concerned has measurable and measurable achievements account transparently. In setting the agenda of activities and funding is always oriented towards an agreement on the basis of deliberation and consensus with all components of the school community.

Teacher profiles, it is expected that in addition to following the statutory provisions related to minimum educational qualifications, certification, and competence, teachers have the autonomy to plan the design of teaching programs (RPP) in accordance with existing facilities and infrastructure and develop curriculum in accordance with the level of student needs. Teachers periodically take self-evaluations and/or assessments among peers and assessments from superiors (principals). In addition, so that teachers always follow the development of science and technology are given the right to attend a variety of professional training that is renewing/strengthening as well as increasing competence. In other words, the teacher as a professional is always committed to carrying out his tasks and needs to follow the development of science and technology in accordance with their individual needs. All school activities, aside from being based on academic programs that have been 
jointly determined by the stakeholders, are also scheduled for various non-academic activities (extra-curricular) based on guided interests and talents. Thus, the program of activities in schools does not only emphasize the process, but also quality products. The following table shows some indicators of the characteristics of effective schools (Burki, 1999).

The education system that prevailed before regional autonomy was centralistic, starting from the introduction of a national curriculum to the very dominant central role in teacher management (specifically for state schools). The center is very dominant and determines in every decision about the process of recruitment, appointment, placement, coaching, and transfer of teachers, as well as from the financial aspect. Public school teacher salaries are determined and paid by the Government even though salaries for elementary school teachers are managed by the province, while salaries for junior and senior secondary teachers are directly paid by the Central Government through the KPKN.

In terms of funds outside the salary allocated by the Government to each school, it is provided by allocating funds from the center to the regions (regencies/cities) based on the number of schools in the area. The fund allocation mechanism is done by calculating the same amount of funds for each school based on the level of education, regardless of the number of students, the location or the level of the economic prosperity of the area. This method contains many weaknesses because it does not pay attention to the aspect of equity (equity) and the need to allocate funds to each school (general and vocational). In terms of salary, it must also be able to meet the needs of each teacher because it concerns welfare and even a sense of justice. So it is necessary to be careful in setting salaries for teachers today.

Through the decentralization process implemented by the Government through Law Number 32/2004 on Regional Government and Law Number 33/2004 on Central-Regional Fiscal Balance it can be assumed that new principles and directions in the management of the education sector refer to the division of authority between the Central Government, provinces, and regencies/cities, and the Central-regional financial balance.

There are eight main objectives of decentralization according to (Hadiyanto, 2004), namely:

1. Accelerate economic growth (accelerated economic development),

2. Increasing management efficiency (increased management efficiency),

3. Distribution of financial responsibility (redistribution of financial responsibility), 
4. Increasing democratization through the distribution of power (increased democratization through the distribution of power),

5. Local control becomes greater through deregulation (greater local control trough deregulation),

6. Market-based education (market-based education),

7. Neutralize the centers of power (neutralizing competing centers of power),

8. Improving the quality of education (improving the quality of education),

According to Hadiyanto (2004), conceptually, there are two types of education decentralization, namely:

1. Decentralization of authority in the education sector in terms of education policy and funding aspects from the central government to regional governments (provincial and district).

2. Decentralized education with a focus on granting greater authority at the school level.

The first concept of decentralization of education relates mainly to regional autonomy and decentralization of governance from the center to the regions, while the concept of decentralization of education that focuses on giving greater authority at the school level is carried out with motivation to improve the quality of education. The goals and orientation of the decentralization of education vary greatly based on the experience of decentralization of education carried out in several Latin American countries, in the United States and Europe. If the objective is the granting of greater authority in the education sector to local governments, then the focus of the decentralization of education undertaken will be on delegating more authority to the local government or the School Board. Implicit in the education decentralization strategy such as this is a target to achieve efficiency in the use of resources (school resources, education funds originating from the government and society).

On the other hand, if the goal of education decentralization is to improve the quality of the teaching and learning process and the quality of the results of the teaching and learning process, then the decentralization of education is more focused on reforming the teaching and learning process. The participation of parents in the teaching and learning process is considered to be one of the most determining factors. 
Educational decentralization is an opportunity for improving the quality of teaching and learning activities in schools. In other words, it is an opportunity for improving the quality of education in each region. This is because of concerns about improving the quality of teachers, improving the quality of management of school principals, improving educational facilities and infrastructure, education funding will be better if it is managed by education officials in the regions. In the end, decentralized education aims to equalize the quality of this improved education.

Decentralization of education is one of the models of education management that makes schools a decision-making process and is an effort to improve the quality of education and human resources, including teacher professionalism, which is currently troubled by various parties both regionally and internationally. Models in the management of quality education will certainly be able to have a very good impact on the education system in Indonesia.

The education system that has been managed in a bureaucratic and centralized climate is considered as one of the causes that have led to a deterioration in the quality and excellence of education in our country. This is reasonable because the bureaucratic system always puts "power" as the most determining factor in the decision-making process. Schools have now been confined by bureaucratic power from central to regional levels, and even seem to be getting worse in the current reform era. Ironically, principals and teachers as those who best understand the reality of education are in a place that is "controlled". They should be the ones who have the most role as decision-makers in overcoming various daily problems that are facing efforts to improve the quality of education. However, they are in a helpless position and are pressured by various standardizations in the form of operational guidelines and technical guidelines that are "certain" not following the objective reality in each school.

Besides that, the power of the bureaucracy is also a factor in the decline in the spirit of community participation in the administration of education in schools. In the past, schools were wholly owned by the community, and it was they who built and maintained schools, provided educational facilities, as well as contributions to provide school operational costs. If they have built a school, the community only asks the government teachers to be appointed to their school. 
At that time, we achieved sustainable education development, because schools are wholly owned by the community who are always responsible for the maintenance and operation of daily education. At that time, the Government was functioning as a counterweight, through the provision of subsidies for assistance to schools to the truly disadvantaged communities.

According to Nugroho (2000), there are at least four advantages to the decentralization of education:

1. Improving quality, namely with the authority of the school, the school is freer to manage and empower the potential of its resources.

2. Financial Efficiency can be achieved by utilizing local tax sources and reducing operational costs.

3. Administrative Efficiency, by cutting long bureaucratic chains by eliminating stratified procedures.

4. Expansion and equity, opening up opportunities for education in remote areas so that there are an expansion and equitable distribution of education.

The weaknesses that may arise in the implementation of education decentralization policies, namely:

1. Lack of human resources in remote areas

2. Unequal regional original income, especially in poor regions

3. Lack of attention from the government and regional government to involve the community more in the management of education

4. The leading authority, in this case, the Regent, Mayor as the sole ruler in the region pays little attention to the condition of education in his area so that the education budget is not yet a top priority

5. Conditions and each region do not have the same power in the administration of education due to differences in facilities, infrastructure and funds owned.

Other opinions expressed by (Kinalova, 2012), the advantages of this decentralization policy have the following advantages:

1. Decentralization is applied in political education efforts

2. To exercise political leadership

3. To maintain political stability 
4. To prevent the concentration of power at the center

5. To strengthen public accountability

6. To increase elite sensitivity to community needs through a public service approach

According to Smith, the above six things can be achieved if the government administration is well organized. In the context of organizing regional government, regional government administration is needed that responds to the aspirations and needs of the community. Therefore, by understanding such an administrative system at the regional level, the interrelated relationships between all components contained in regional government administration as a whole to achieve the goals that have been set more quickly achieved. It is very much needed for a partnership of all blood components.

In addition to strengths, of course, decentralization also has weaknesses, according to (Kinalova, 2012), the lack of decentralization, namely:

1. Because the number of government organs has increased in line with the authority of the region, the structure of government has become more complex, making coordination difficult.

2. The relationship between balance and harmony between various kinds of regional interests is easily disturbed.

3. Territorial decentralization can encourage "regional sentiment" (ethnocentric).

4. Decision making requires a long time due to complicated negotiations.

5. The implementation of decentralization requires more costs and is difficult to implement simply and uniformly.

Facing the era of information technology advancement and the 4.0 revolution, the Indonesian government must further innovate in terms of curriculum, systems, and infrastructure to support the readiness of the next generation to face the 4.0 revolution. Thus education and training and development in human resources and the completeness of facilities and infrastructure to support the development of this era. Based on research conducted by researchers some time ago in Central Java, researchers found some schools are innovating in teaching and learning activities. The innovation that the school did was to provide access to teaching and learning through digital media in the form of videos, in which the video contained material that the teacher represented in the classroom. This video can be accessed by students when the student is unable to attend school due to illness or 
permission. The purpose of the school to do this is to minimize students lag behind the subject matter. Researchers also found another policy, namely in the area of East Java, precisely in Batu city, where the government, in this case, the regional education office developed the potential of the region by including the tourism curriculum. The inclusion of this curriculum is considered important by the local government so that students can develop the potential of their regions, but also do not reduce the standards that the central government provides.

In addition, according to Marihot Manulang, there are at least 4 positive aspects to support the policy of education decentralization, namely: 1) Quality improvement, namely with the authority possessed by schools, schools are freer to manage and empower the potential of their resources; 2) Financial efficiency can be achieved by utilizing local tax sources and reducing operational costs; 3) Administrative efficiency, by cutting long bureaucratic links by eliminating stratified procedures; 4) Expansion and equity, opening up opportunities for education in remote areas so that there are an expansion and equitable distribution of education. So that decentralization can be said as scenario planning in dealing with revolution 4.0 if it is optimized by the central government and regional governments.

The concept of educational decentralization refers to transfer - if it does not say the division of decision making authority and responsibility for carrying out tasks. Specifically, namely the process of transfer of authority (transfer of authority) in educational organizations from one higher level to another lower level. The level of authority in education itself lies at four levels: central government, provincial, district, or district/city government, and schools or education units (Welsh and McGinn, 1999).

Some principles in the decentralization of education proposed by Welsh and McGinn (1999) that in principle, decentralization applies to all important functions including the education sector, including in terms of (1) planning and monitoring implementation plans; (2) budget and financial management; (3) personnel management; (4) academic management; and (5) infrastructure provision including procurement. In detail the four things thought in seeing the decentralization of education can be explained in an ideal theoretical concept as follows: 
(1) Planning, implementation, and monitoring: in all countries, the Central Government retains the function of national policy regulation and in most countries for national planning, including long-term and medium-term planning. In some countries, the strategic planning function is also the responsibility of regional or provincial entities. For educational levels considered strategic, such as secondary education in many countries, school mapping remains a centralized function while responsibilities have been left to lower levels of government for basic education. As a result of decentralization, monitoring is increasingly hungry for information and evaluation systems are growing in the education sector throughout the world.

(2) Budget and financial management: budget preparation and allocation, expenditure management and monitoring are joint responsibilities between the Center and regional governments. There are countries where the Ministry of Education is not involved in the budget allocation process. In many countries, an education budget of around $80 \%$ is implemented through local government budgets. This shows that in essence, education funding has been far more decentralized.

(3) Personnel management: in many countries the decision power is in the personnel management function, as a key, especially in the distribution of personnel and, remains the central government tool that most determines the implementation of national planning to direct and influence regional planning decisions.

(4) Academic management: in most countries, governments maintain central control over learning content and standards through the curriculum. Decentralized academic management functions are limited to extra-curricular activities with local content, flexibility with schedules to implement the specified core curriculum, authorization to select reading material. In countries with a tradition of decentralization in academic matters, there is a tendency towards re-centralization in terms of curriculum, related to concerns about academic standards and the level of qualification under conditions of economic competition pressure. Learning performance appraisal policies, including the national examination system and standard entry requirements for higher levels of education, act as a strong element of centralization even in systems with high levels of school autonomy. 
(5) Provision of infrastructure: in many countries' functions related to infrastructure planning, financing, maintenance have been decentralized to lower levels of government and local communities. They concern spending, especially capital. The organizational context, including the concrete ways in which certain key functions are being implemented and monitored (for example through a system of vertical relations and horizontal relations, the structure and operation of the Ministry of Education) forms the process of education policy formulation, planning, including financial planning, and allocation of resources and methods course resources that have been used. This relates to the budget planning policy process in the context of decentralization. It focuses on education planning and implementation monitoring. The term decentralization is used primarily concerning education reform in the community education sector, namely educational activities financed from the public budget.

\section{Conclusion}

This paper concludes that decentralization in the field of education can be made as scenario planning in the face of the 4.0 revolution. As the researchers found both in the literature study and field study of the decentralization of education that took place in Indonesia has led to the 4.0 revolution. But there are still some deficiencies in the resources owned by the government and also from the advice and infrastructure to support the ongoing quality education.

In practice, the decentralization of education has led to the readiness to face the 4.0 revolution, but there are still shortcomings including readiness from the teaching staff and other supporting suggestions. The decentralization of education can be used as a model by the government to deal with the times in the digital revolution 4.0. With proper management and further innovation in the system, the education concentration can be made as a way to achieve the readiness of the next generation to face the 4.0 revolution. the results of this research can be used by academics in the future, especially raising the theme in this scenario planning, so that it can become a new study, especially in developing the concept of social science. 


\section{References}

Chau, T. (1985). Equity and the decentralization question. In: Lauglo, J. and McLean, M. (1982). The control of education. University of London. Institute of Education.

Burki, S. J., Perry, G., Dillinger, W., Griffin, C., Gutman, J., Rojas, F., . . Winkler, D. (1999). Beyond the center: Decentralizing the state: The World Bank.

Hermann, M., Pentek, T., \& Otto, B. (2016). Design principles for industrie 4.0 scenarios. System Sciences (HICSS), 49th Hawaii International Conference, pp. 3928-3937.

Erkan, Senem Seda Sahenk. (2013). A Comparison Of The Education Systems In Turkey And Singapore And 1999-2011 Timss Test Result. Procedia-Social And Behavioral Sciences, 5564 doi : 10.1016/j.sbspro.2013.12.008

Hoogerwerf, A. (2003). Beleid, processen en effecten [Policy processes and policy effects]. In A. Hoogerwerf \& M. Herweijer (Eds.), Overheidsbeleid [Public policy] (pp. 17-36). Deventer, Netherlands: Kluwer.

McGinn, N., \& Welsh, T. (1999). Decentralization of education: why, when, what and how? International Institute for Educational Planning, 9-99.

Merkel, A. (2014). Speech by Federal Chancellor Angela Merkel to the OECD Conference. https://www.bundesregierung.de/Content/EN/Reden/ 2014/2014-02-19-oecd-merkelparis_en.html, Diakses pada 11 Maret 2017.

Kagermann, H., Lukas, W.D., \& Wahlster, W. (2011). Industrie 4.0: Mit dem Internet der Dingeauf dem Weg zur 4. industriellen Revolution. http://www.vdinachrichten.com/Technik-Gesellschaft/Industrie-40- Mit-InternetDinge-Weg-4-industriellen-Revolution, Diakses pada 17 Juni 2017.

Kagermann, H., Lukas, W.D., \& Wahlster, W. (2013). Final report: Recommendations for implementing the strategic initiative INDUSTRIE 4.0. Industrie 4.0 Working Group.

Kinalova. (25 September 2017). Kelebihan dan Kelemahan Desentralisasi Pendidikan, (Online), http://kinalova.blogspot.com/2012/09/kelebihan-dan-kekurangansentralisasi.html,

Nugroho, Riant. (2000). Desentralisasi Tanpa Revolusi. Jakarta: Elex Media Komputindo.

Morrison, G. M., \& Allen, M. R. (2007). Promoting Student Resilience in School Contexts. Theory into Practice, 46, 162-169. http://dx.doi.org/10.1080/00405840701233172. 
Peraturan mentri pendidkan dan kebuayaan nomor 24 tahun 2016 tentang tentang Kompetensi Inti dan Kompetensi Dasar Pelajaran pada Kurikulum 2013 pada Pendidikan Dasar dan Pendidikan Menengah (Berita Negara Republik Indonesia Tahun 2016 Nomor 971).

Schlechtendahl, J., Keinert, M., Kretschmer, F., Lechler, A., \& Verl, A. (2015). Making existing production systems Industry 4.0-ready. Production Engineering, Vol. 9, Issue.1, pp.143-148.

Undang-Undang Dasar Republik Indonesia Tahun 1945 Undang-Undang Republik Indonesia, Nomor 32 Tahun 2004 Tentang Pemerintahan Daerah (hasil revisi).

Undang-Undang Republik Indonesia, Nomor 18 Tahun 1997 Tentang Pajak Daerah dan Retribusi Daerah.

Undang-Undang Republik Indonesia, Nomor 33 Tentang Perimbangan Keuangan antara Pemerintah Pusat dan Daerah (hasil revisi). 